\title{
Implementation of Augmented Physics Animation Integrated Crosscutting Concept COVID 19 in Facilitating Problem Solving Skills and Disaster Preparedness
}

\author{
Yudi Guntara ${ }^{\text {a) }}$, Indri Sari Utami ${ }^{\text {b) }}$ \\ Department of Physics Education, Universitas Sultan Ageng Tirtayasa, Ciwaru Raya, Serang 42117, \\ Indonesia \\ $\varangle$ : a) guntaray@untirta.ac.id, b)isu_indrisariutami@untirta.ac.id
}

\begin{abstract}
This study aimed to implement augmented physics animation integrated crosscutting concept COVID-19 in facilitating student problem-solving skills and disaster preparedness. This study used a quantitative approach. The research design chosen was a pre-experimental design with a posttest-only design with nonequivalent groups. The research was conducted at the Department of Physics Education, Universitas Sultan Ageng Tirtayasa. All students of the department are the research population. The sampling technique used was purposive sampling. The number of 35 students entered the experimental group, and 36 students entered the comparison group. The results showed that a) there was no difference in students' mastery of problem-solving skills in the experimental and comparison group. Asymp. Sig indicates a value of 0.187 or $>0.05$, so it can be decided that $\mathrm{H} 1$ was rejected. b) There was a difference in the level of student COVID19 disaster preparedness between the experimental and the comparison group. Asymp indicated this. Sig was 0.012 or $<0.05$, so it could be decided that $\mathrm{H} 2$ was accepted. Therefore, it can be concluded that the implementation of augmented physics animation on the mastery of student problem-solving skills has not yet been seen but can already be seen in facilitating the level of preparedness of students in dealing with the COVID-19 disaster.
\end{abstract}

Keywords: augmented reality, crosscutting concept, COVID-19 disaster preparedness, problem solving skills

\section{INTRODUCTION}

One of the 21st-century skills that pre-service physics teacher students must master is problemsolving skills (Ekici 2014; Sağlam and Dost 2014; Valtonen et al. 2021). Various studies have been conducted to improve student problem-solving skills, especially physics. Several studies include using the help of learning models such as the application of problem-based models (Warimun 2012), creative problem-solving models (Hariawan, Kamaluddin and Wahyono 2013), problem-solving models based on experiments (Nugraha et al. 2017), and collaborative problem-solving models (Afrizon and Dewi 2019). However, the majority only focus on using learning models, and there are still a few studies that use the help of instructional media, mainly based on augmented reality technology.

Physics is one of the science subjects that can develop inductive and deductive analytical thinking in solving problems related to natural events around (Astra, Raihanati, and Mujayanah 2020). Problemsolving activities are a series of processes consisting of several stages. These steps can consist of several steps, including the exact steps, such as identifying the problem, analyzing, finding out, and implementing the solution (Memduhouglu and Kelecs 2016; Aristiawan and Istiyono 2020). Because 
Physics is very closely related to mathematics or the language of delivery is mathematics, but if you focus too much on mathematics alone, it will prevent students from learning other essential parts of solving physics problems. So, prospective physics teacher students need to master these skills to construct knowledge into deep understanding. So that students can quickly build their knowledge, a media that can support them is required. One of the possible media is media based on augmented reality technology. The advantage of this technology is that it makes a concept look real because it manifests in a 3D image. Jeffri and Awang Rambli (2021) explained that the augmented reality (AR) system had been shown to affect mental workload and performance in various application contexts positively. However, this needs to be supported by other factors, namely the contextual packaging of the material.

It has been almost a year that COVID-19 has hit the world. The problem of COVID-19 can actually be studied with physics. Therefore, learning should be packaged contextually so that learning is more meaningful and forms individual problem solvers. Also, if physics learning is linked to the COVID-19 pandemic, it will increase students' preparedness for this pandemic. Knowledge is a significant factor and a key to readiness (Natalia, Malinti, and Elon 2020). The knowledge they have can usually influence attitudes and concerns to be prepared to anticipate disasters (Zahro et al. 2017). The main factors that can cause the disaster to cause significant casualties and losses, namely a lack of understanding of the characteristics of hazards, attitudes, or behaviors that result in a decrease in natural resources, lack of early warning information resulting in unpreparedness, and helplessness or inability to face disasters (Umar 2013). Based on the explanation above, this study aims to implement augmented physics animation integrated cross-cutting concept COVID-19 to facilitate student problem-solving skills and disaster preparedness. The hypotheses in this study include:

$\mathrm{H}_{1}$ : There are differences in students' mastery of problem-solving skills between the experimental group and the comparison group

$\mathrm{H}_{2}$ : There is a difference in the level of COVID-19 disaster preparedness between students in the experimental group and the comparison group.

\section{METHODS}

This study uses a quantitative approach because it has the aim of testing a hypothesis. The research design chosen was quasi-experimental in the form of static group comparison. This design was selected because it wanted to see the treatment application in a group (experimental group) and compared with other groups (control group without application of treatment) by looking at the final results only. This design was chosen because it was intended for an initial trial regardless of the effectiveness of the applied treatment. This research was conducted at the Department of Physics Education, Universitas Sultan Ageng Tirtayasa. All students of the study program are the research population. The sampling technique used was purposive sampling. The 35 students entered the experimental group, and 36 students joined the comparison group. All students are willing to be a sample and do research. The learning model used in both groups is the same, namely the problem-solving learning model, according to Sitti, Sopeerak, and Sompong (2013). The learning model is a control variable in research. Meanwhile, treatment is appropriate media, namely the Augmented Physics Animation (APA) integrated crosscutting concept for COVID 19 (Guntara et al. 2021), applied to the experimental group. The research design schematic is shown in TABLE 1.

TABLE 1. Pre-experimental design with posttest only design with nonequivalent

\begin{tabular}{lll}
\hline Group & Treatment & Posttest \\
\hline Experiment & $\mathrm{X}$ & $\mathrm{O}$ \\
\hline Comparison & - & $\mathrm{O}$ \\
\hline
\end{tabular}

Information:

$\mathrm{X}=$ Use of Augmented Physics Animation integrated crosscutting concept COVID-19

$\mathrm{O}=$ Output of problem solving tests and COVID-19 disaster preparedness

The research was carried out in a hybrid way, i.e., offline learning was carried out with health protocols when providing material, and follow-up and tests were online or uploaded online. Collecting data on problem-solving skills in both groups used the test method in the form of descriptions. Aspects 
of problem-solving skills adapted from the research results of Aristiawan and Istiyono (2020), consisting of 1) understanding the problem; 2) organizing the knowledge; 3) carrying out the plans; and 4) evaluating the solution. The test consists of 4 questions with the material's details: unit quantities and measurements, kinematics, and electromagnetic waves. This material was chosen because it relates to COVID 19, and the items are related to that concept. In detail, the item questions are presented in TABLE 2.

TABLE 2. Problem solving skills item question

\begin{tabular}{llll}
\hline $\begin{array}{l}\text { Aspects of } \\
\text { Problem Solving }\end{array}$ & Indicators & Topics & Item Questions \\
\hline $\begin{array}{l}\text { Understanding the } \\
\text { problem }\end{array}$ & $\begin{array}{l}\text { Group the information } \\
\text { needed and not needed in } \\
\text { calculating the diameter } \\
\text { of the SARS Cov-2 virus. }\end{array}$ & $\begin{array}{l}\text { Quantities, } \\
\text { Units, and } \\
\text { Measurement }\end{array}$ & Look at the following picture \\
& & & Transmission Electron Microscope or TEM
\end{tabular}

Transmission Electron Microscope or TEM micrograph image of SARS Cov-2 virus particles from a sample of COVID-19 patients (by NIAID, Integrated Research Facility (IRF), Ford Detrick, Maryland). The size of a human cell is about $1,000 \mathrm{x}$ the virus, and the size of a red blood cell is about $7,000 \mathrm{~nm}$. Image captured at 500,000 x magnification. The image is $2.5 \mathrm{~cm}$ wide. It is known that in $1 \mathrm{~m}^{2}$, the area can be inhabited by about $800,000,000$ viruses. Based on the above explanation, which information is needed and not needed to determine the actual diameter of the SARS Cov-2 virus? And also, determine the diameter of the SARS Cov-2 virus if expressed in $\mathrm{nm}$ ! (20 points)

\begin{tabular}{ll}
\hline $\begin{array}{l}\text { Organizing the } \\
\text { knowledge }\end{array}$ & $\begin{array}{l}\text { Making a mathematical } \\
\text { equation for the distance } \\
\text { to fall in droplets } \\
\text { containing the SARS } \\
\text { Cov-2 virus }\end{array}$
\end{tabular}

SARS Cov-2 virus transmission can occur through droplets that come out when a patient coughs or sneezes. The droplets' size is more significant than aerosols, so the droplets fall to the ground more quickly. If one day there is a wind with a constant velocity $\left(v_{\mathrm{w}}\right)$ that blows in the same direction as the outward droplet $\left(v_{\mathrm{d}}\right)$, determine the horizontal droplet fall distance equation when there is no wind $\left(x_{1}\right)$ and when there is wind $\left(x_{2}\right)$ ! All other factors are ignored. (20 points)

\begin{tabular}{llll}
\hline $\begin{array}{l}\text { Carrying out the } \\
\text { plans }\end{array}$ & $\begin{array}{l}\text { Analyzing the dimensions } \\
\text { of the droplet critical } \\
\text { distance equation } \\
\text { generated by a patient } \\
\text { infected with SARS Cov- }\end{array}$ & $\begin{array}{l}\text { Quantities, } \\
\text { Units, and } \\
\text { Measurement }\end{array}$ & $\begin{array}{l}\text { Some researchers have formulated an equation to } \\
\text { determine the critical distance produced when a } \\
\text { SARS Cov-2 patient is talking. } \\
\text { The equation is: }\end{array}$ \\
& $\begin{array}{l}v_{e} t_{s}+\left(v_{t}-v_{e}\right) \tau\left(1-e^{-\frac{t_{s}}{\tau}}\right)=\frac{L_{m}}{2}-L_{z} \\
\tau=\frac{2 \rho_{d} r^{2}}{9 \mu_{a}}\end{array}$ \\
& $\begin{array}{l}\text { Where: } \\
\text { Information: }\end{array}$ \\
\hline
\end{tabular}




\begin{tabular}{|c|c|c|c|}
\hline $\begin{array}{l}\text { Aspects of } \\
\text { Problem Solving }\end{array}$ & Indicators & Topics & Item Questions \\
\hline & & & $\begin{array}{l}v_{e} \text { is the velocity of fall of the aerosol particles } \\
\text { assuming the gravitational force is balanced with } \\
\text { the bouyancy and drag of the air; } v_{t} \text { is the } \\
\text { downward velocity of the aerosol particles as } \\
\text { they dry out; }{ }^{\tau} \text { is droplet time (ignore the Brown } \\
\text { move); } \rho_{d} \text { is the density of the droplets; } \mathrm{r} \text { is the } \\
\text { droplet radius; } \mu_{a} \text { is the coefficient of air } \\
\text { viscosity; } \mathrm{L}_{z} \text { and } \mathrm{L}_{\mathrm{m}} \text { is distance. Is this equation } \\
\text { correct if proven by using dimensional analysis? } \\
\text { (20 points) }\end{array}$ \\
\hline $\begin{array}{l}\text { Evaluating the } \\
\text { solution }\end{array}$ & $\begin{array}{l}\text { Evaluating a statement } \\
\text { regarding the benefits of } \\
\text { electromagnetic waves in } \\
\text { destroying SARS Cov-2 }\end{array}$ & $\begin{array}{l}\text { Electromagnetic } \\
\text { wave }\end{array}$ & $\begin{array}{l}\text { Ultraviolet (UV) rays that come to earth consist } \\
\text { of UV-A, UV-B, and UV-C. Several studies have } \\
\text { shown that the UV-C type is very effective as a } \\
\text { disinfectant because it can destroy the genetic } \\
\text { structure of the SARS Cov- } 2 \text { virus. UV-C has the } \\
\text { longest wavelength and highest energy. The most } \\
\text { UV radiation that reaches the earth is UV-C } \\
\text { because some UV-B and all UV-A are absorbed } \\
\text { by ozone. } \\
\text { Evaluate whether the above statement is correct? } \\
\text { If it's not quite right, explain your reasons! ( } 20 \\
\text { points) }\end{array}$ \\
\hline
\end{tabular}

The experimental and comparison groups' data collection for COVID-19 disaster preparedness was carried out using a dichotomy scale questionnaire. Disaster preparedness questionnaire indicators adapted from Yanti et al. (2020) and Zahro et al. (2017) with aspects of fundamental knowledge about COVID-19 and student behavior during the COVID-19 pandemic. Analysis of test and questionnaire data used non-parametric statistics, namely the Mann-Whitney $U$ test. This analysis used the assistance of the IBM SPSS Statistics 24 program. This analysis uses the help of the IBM SPSS Statistics 24 program. Both data, both problem-solving data and questionnaire data, use a polynomial scale so that the study can use different tests.

\section{RESULTS AND DISCUSSION}

\section{Mastery of problem solving skills}

The first research hypothesis in this study relates to the mastery of student problem-solving skills with augmented physics animation integrated crosscutting concept COVID-19. The analysis results using IBM SPSS Statistics 24 obtained an average score of problem-solving skills in the experimental group $(\mathrm{N}=35)$ of $\bar{x}_{e k s}=40.57$; $\mathrm{SD}=6.39$. Meanwhile, the comparison group $(\mathrm{N}=36)$ obtained an average of $\bar{x}_{p b d}=38.47 ; \mathrm{SD}=8.18$. When compared directly to the average score, it will be seen that the mastery of problem-solving skills in the experimental group is higher than the comparison group. Meanwhile, if analyzed using non-parametric statistics, namely the Mann-Whitney U test, the results obtained are as shown in TABLE 3. Non-parametric statistics were selected because the sample was not randomly selected, and the prerequisite for the different tests was not fulfilled; namely, the data were not normally distributed.

TABLE 3. Mann-Whitney U Test Results

\begin{tabular}{lll}
\hline No & Aspects & Values \\
\hline 1 & Mann-Whitney U & 518.000 \\
\hline 2 & Wilcoxon W & $1,184.000$ \\
\hline 3 & Z & -1.321 \\
\hline 4 & Asymp. Sig. (2-tailed) & 0.187 \\
\hline
\end{tabular}


Asymp. Sig indicates a value of 0.187 or greater than 0.05 . Then it can be decided that $\mathrm{H}_{1}$ is rejected, meaning that there is no difference in the mastery of student problem-solving skills in the experimental and comparison groups. In contrast, the distribution of student mastery of problem-solving skills based on each aspect can be seen in FIGURE 1.

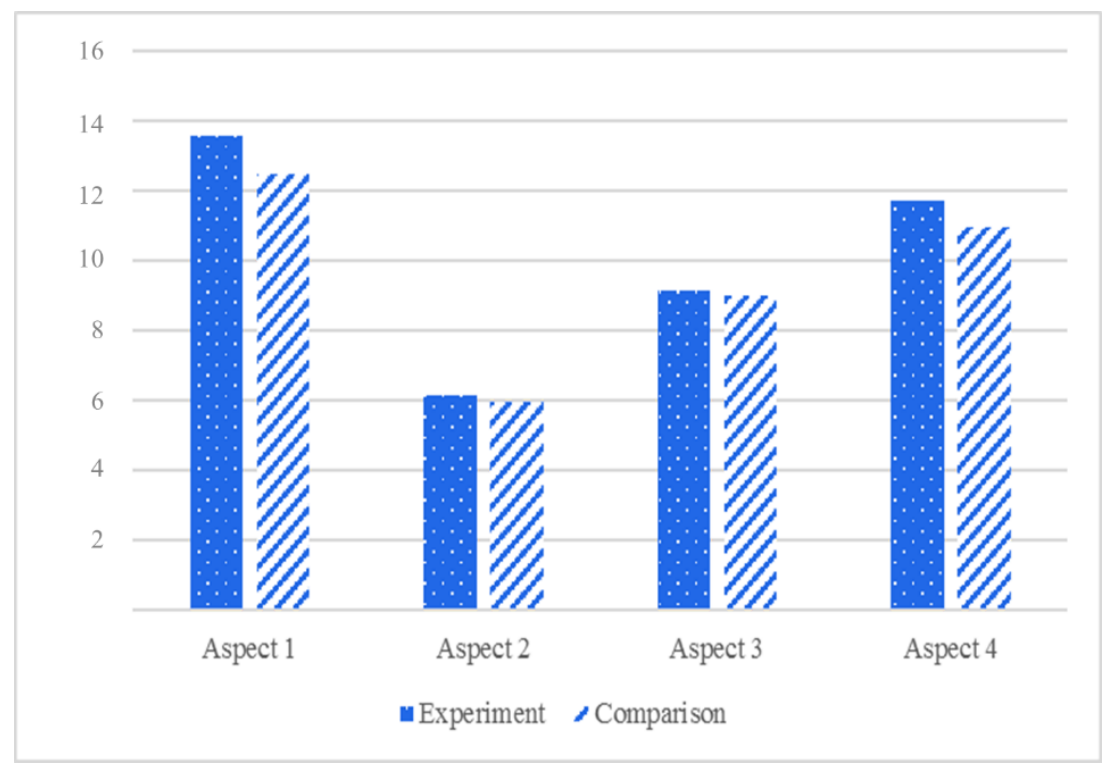

FIGURE 1. Distribution of students' mastery of problem-solving skills based on each aspect

Aspect 1 (understanding the problem) and aspect 4 (evaluating the solution) were on average controlled by students as indicated by an average score of $>65 \%$ (average score of 13 points out of 20 points) in both groups. The mastery of aspect 3 (carrying out the plans) is around $45 \%$, including the low category, and aspect 2 (organizing the knowledge) is the most difficult for students to master with a score percentage of only $30 \%$. The discussion for each aspect is discussed further in the following explanation.
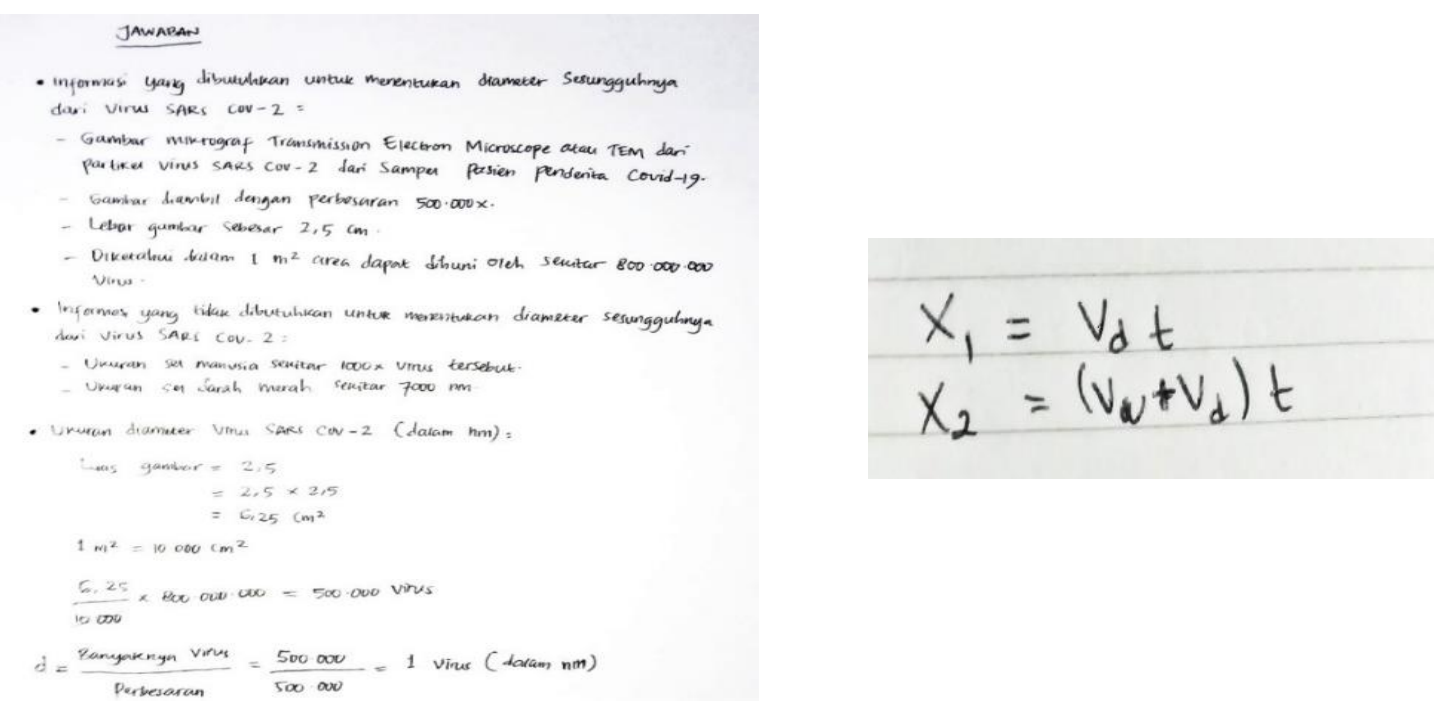

FIGURE 2 (a). Sample student answers on the aspects of understanding the problem; (b) Sample student answers on the aspects of organizing the knowledge

FIGURE 2 (a) shows the answer of one of the students who did not master understanding the problem. This aspect is intended to reveal the student's ability to understand problems through information filtering. However, based on FIGURE 2 (a), the student was wrong in grouping the information. Information is not related but categorized into groups of information needed, such as 
information "about 800,000,000 viruses can inhabit $1 \mathrm{~m} 2$ area". This information is meaningful but irrelevant when used to determine the actual diameter of the virus. In deciding the diameter, there is also an understanding error. In this item, when viewed from the material, students need to master material on unit conversion and the rules of writing scientific notation. The method used is quite simple; namely, the size of the virus image resulting from TEM scanning of $2.5 \mathrm{~cm}$ is converted to $2.5 \times 10^{7}$ $\mathrm{nm}$, divided by 500,000x magnification, so the virus diameter is $\mathrm{d}=50 \mathrm{~nm}$. However, if you see an answer to FIGURE 2 (a), the student does not understand the meaning or direction of the problem. Also, the fatal mistake was when students assumed that the number of viruses' units was the same as the length units. The students were fooled by the unnecessary information and put it into the calculations. By Hidayati's (2017) research, the selection of data will impact problem analysis. These students experience cognitive overload not to filter information properly (Fong, Lily, and Por 2012). This condition can be overcome by getting used to giving questions in this form so that students can filter the information needed (Kwon, Kumalasari, and Howland 2011). The ability to select or filter this information significantly impacts the mastery of problem-solving skills and is the starting point that determines the steps to solve problems (Argelagós and Pifarré 2012).

FIGURE 2 (b) shows students' answers related to organizing the knowledge. This aspect reveals the student's ability to solve physics problems by linking physics principles or concepts. This condition can make students confused in finding out the correct physics concept. As shown in FIGURE 1, many students could not answer this item, both in the experimental and comparison groups. For example, FIGURE 2 (b) shows that the answer is by the direction of the questions, but the student cannot link concepts. The response has led to the idea of straight motion with constant velocity (GLB), but in determining the time, they have not been able to decide. Supposedly, the time it takes for the droplet to fall to the ground is obtained by the concept of free-fall motion. Why is motion-free fall? Because the problem is given information if the direction of the initial droplet velocity is horizontally straight. Thus, the droplet motion about the y-axis is considered to experience free fall motion shown by the form of a half parabola trajectory. Through these items, it can be revealed if students still experience confusion in linking physics concepts. The concept of physics in this item is simple, namely vectors and kinematics of straight motion. However, it is suspected that students still have difficulty understanding physics concepts, so that if they are faced with questions related to various kinds of concepts, they will experience problems. This is in line with the research of Ignacio Madrid, Van Oostendorp, and Puerta Melguizo (2009) and Ploetzner et al. (2009), which explain that understanding basic concepts is the key to mastery in linking between concepts.
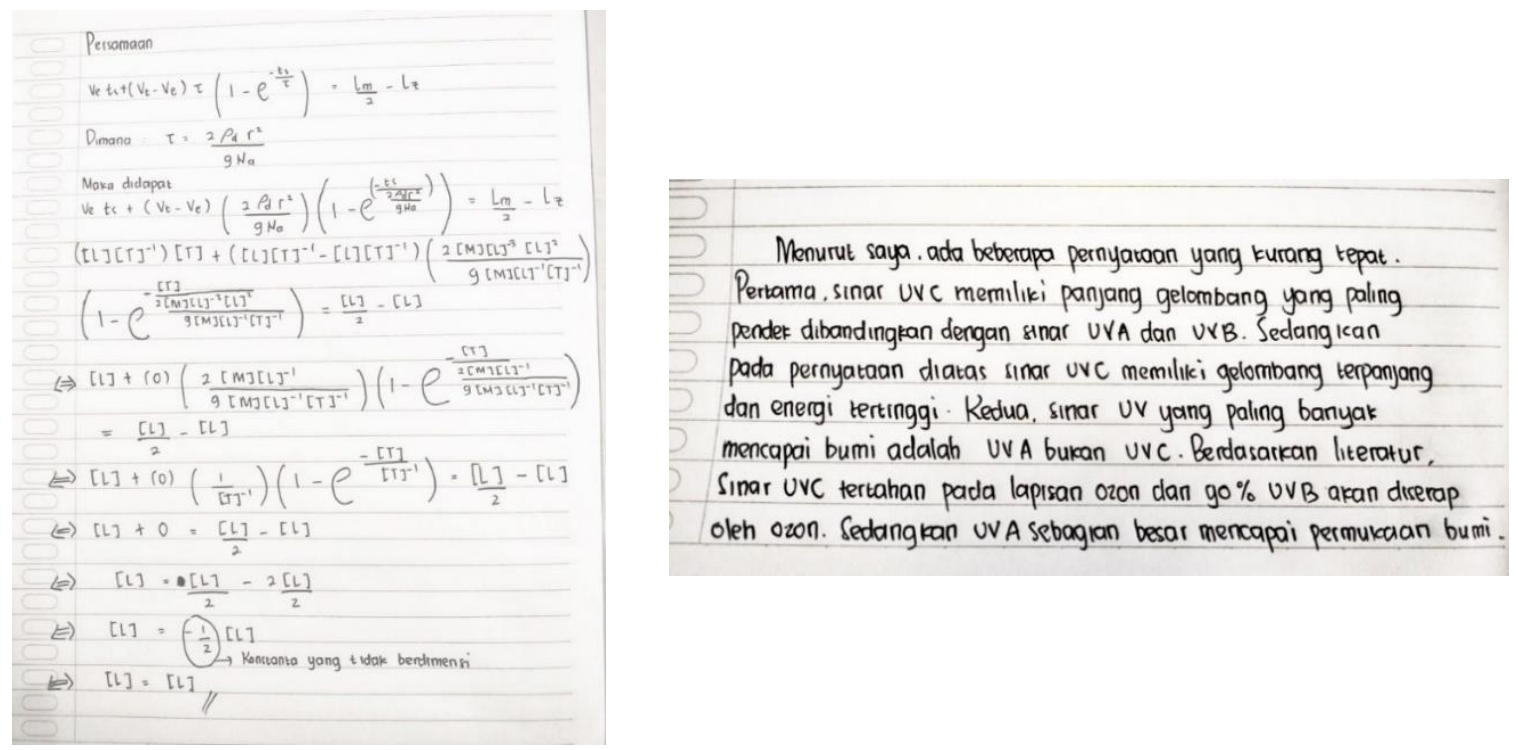

FIGURE 3 (a). The sample of students' answers is on the aspects of carrying out the plans; (b) Sample student answers on the aspect of evaluating the solution

FIGURE 3 (a) shows the answers related to the carrying out aspects of the plans. This aspect wants to reveal the student's ability to plan proof or strategies to find the right solution (Taasoobshirazi and 
Farley 2013). Examples of this ability are to perform multiplication, division, simplification, substitution, etc,. which are required through the analysis process. In FIGURE 3 (a), students are directed to prove the droplet drop distance equation's truth using dimensional analysis. In dimensional analysis, there are several simple mathematical operations. The student's answer's final result has proven that the right and left segments match the dimensions. However, if you look at the process of answering these questions, there are several mistakes. Students assume that dimensional analysis is the same as ordinary mathematical operations, for example, in the second term. According to the student, the subtraction operation " $\mathrm{v}_{\mathrm{t}}-\mathrm{v}_{\mathrm{e}}$ " will cause the quantity to be dimensionless. Based on his thinking, dimensional operations are the same as ordinary mathematical operations, such as "2-2 $=0$ ". Therefore, because it considers "zero" to be dimensionless, then it is concluded that it has no dimension in the second term. The " $\mathrm{v}_{\mathrm{t}}-\mathrm{V}_{\mathrm{e}}$ " operation should still have a dimension, namely the dimension of speed.

Likewise, for terms that have exponents, namely “ $1-e^{-\frac{t_{s}}{\tau}}$ ". The term should have no dimensions. In simple terms, you can see a number "1", meaning that the exponential part should also be a value without dimensions. However, if you look at the student's answer, the term exponential still has dimensions. The critical point on this item is the ability to analyze comprehensively. According to Docktor (2009), even though the final result of solving the questions is correct, if the analysis process is wrong, it can be categorized as having not mastered problem-solving skills.

FIGURE 3 (b) shows the aspects related to evaluating the solution. This point wants to reveal the student's ability to reconsider, check answers, find out arguments and conclusions from the problemsolving process. Most of the students' responses were correct, and they already understood how to evaluate correctly. The question statement is erroneous, as in the description of UV-C characteristics, its wavelength, and its energy. However, with the student's knowledge and understanding, the question statement can be corrected. This is in line with Safitri and Toyib's (2019) research results, which explain that the ability to evaluate answers can be controlled if the individual understands the knowledge obtained.

Based on the results of the analysis shown in TABLE 3 and FIGURE 1, it can be concluded that the implementation of augmented physics animation on students' mastery of problem-solving skills is still not effective. This happens because the augmented physics animation media only facilitates two aspects of problem-solving skills, such as understanding the problem related to selecting information from various sources about COVID-19 and physics. And the aspect of organizing the knowledge is linking physics concepts on issues about the COVID-19 pandemic. But in reality, even in managing the learning, students still do not master it even though it has been facilitated. Many factors influence, including the level of students' understanding of fundamental physics, is still low, and they have not made a comprehensive connection between physics concepts. Besides, the development of augmented physics animation is only a supplement and prioritizes the integration of several fields of study so that the discussion of COVID-19 can be studied comprehensively (Guntara et al.c 2021).

\section{Level of COVID-19 disaster preparedness}

This study's second objective is to see the effectiveness of augmented physics animation in COVID19 disaster preparedness. The distribution of student preparedness to face the COVID-19 disaster can be seen in TABLE 4.

TABLE 4. Distribution of student preparedness to face the COVID-19 disaster

\begin{tabular}{lllll}
\hline Group & Level & $\boldsymbol{f}$ & \% & Asymp. Sig. (2-tailed) \\
\hline \multicolumn{2}{l}{ Aspects of student knowledge about the COVID-19 pandemic } & \\
\hline \multirow{2}{*}{$\begin{array}{l}\text { Experiment } \\
(N=35)\end{array}$} & Good & 30 & 85.71 \\
\cline { 2 - 4 } & Not good & 5 & 14.29 \\
\hline \multirow{2}{*}{$\begin{array}{l}\text { Comparison } \\
(N=36)\end{array}$} & Good & 20 & 55.56 \\
\cline { 2 - 4 } & Not good & 16 & 44.44 \\
\hline Aspects of student behavior during the COVID-19 pandemic & \\
\hline Experiment & Good & 25 & 71.43 \\
\cline { 2 - 4 } & Not good & 10 & 28.57 \\
\hline Comparison & Good & 18 & 50.00 \\
\cline { 2 - 4 } & Not good & 18 & 50.00 \\
\hline
\end{tabular}


Judging from TABLE 4, in student knowledge about the COVID 19 pandemic, the experimental group was better than the comparison group with a difference of about $30.15 \%$. This is because augmented physics animation media is a combination of print media in handouts integrated with augmented reality technology (3D images). So, students tend to prefer and be motivated to study physics to integrate the COVID-19 theme. This is shown in Guntara et al. (2021) using the instructional materials motivation survey (IMMS), which obtained high motivation values. Some displays of the use of augmented physics animation in the group room are shown in Figure 4. Experiment and comparison groups have been given material related to COVID-19. However, the experimental group used augmented physics animation, and the comparison group used the lecturer's media, namely, PowerPoint. It is possible that the media influence this aspect of knowledge developed. It could be influenced by other factors such as students' initial knowledge that each individual already has through reading or watching the news. However, to test this, before being given a preparedness questionnaire, a question was asked about whether there might have been external factors that influenced individual knowledge. From the results of the answers, it shows that only $20 \%$ of individuals have ever or often read information related to COVID-19. Therefore, it can be concluded that there is a big influence on using the developed media.

In the aspect of student behavior during the COVID-19 pandemic, the experimental group was still better than the comparison group, with a percentage difference of $21.43 \%$. This is because students can see firsthand the virus forms, how the transmission mechanism is, and others, as shown in FIGURE 4 (b). According to their knowledge, students do not just imagine and are aware of the importance of good behavior during the COVID-19 pandemic. However, if we look at each group, there is a finding. For example, in the experimental group, students who are good at knowledge about COVID-19 are not in tune with their everyday life behavior. This is indicated by a decrease in the percentage from 85.71 (knowledge aspect) to 71.43 (behavioral aspect). Likewise, the results are similar in the comparison group. Indeed, it is not a guarantee if individuals are good at knowledge about COVID-19, both in their behavior in everyday life (Gannika and Sembiring 2020; Wairata 2020). It can be concluded that H2 is accepted, meaning that the application of augmented physics animation media is effective in facilitating COVID-19 disaster preparedness, as indicated by the results of the Mann-Whitney U test at the Asymp. Sig. value (2-tailed) of 0.012 or $<0.05$. Because it has indirectly prepared the psychological aspect. Psychological preparedness comprises two broad mental dimensions or domains: a mostly cognitive aspect directed at the threat, involving knowledge of the threat environment and adaptive responses, and a mostly affective aspect involving self-awareness and emotional self-control (Mclennan, Marques, and Every 2020).

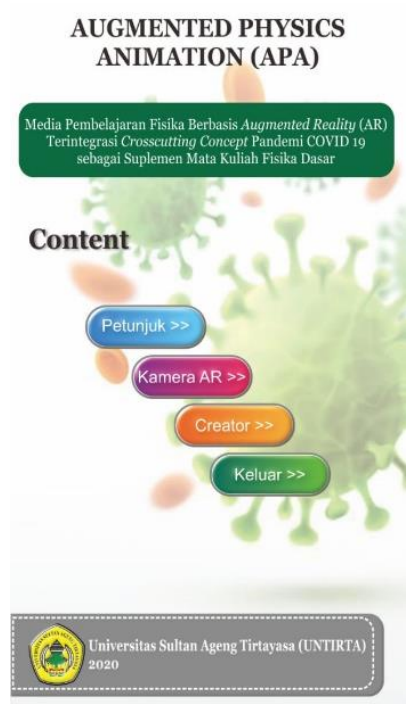

(a)

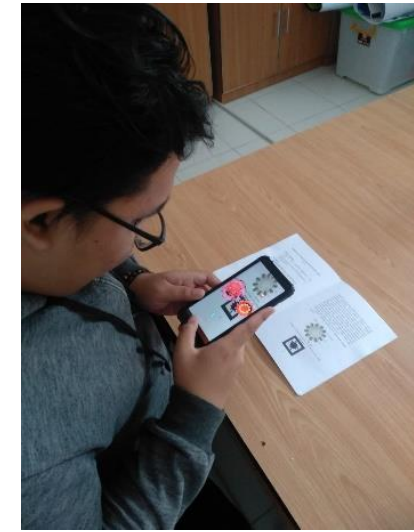

(b)

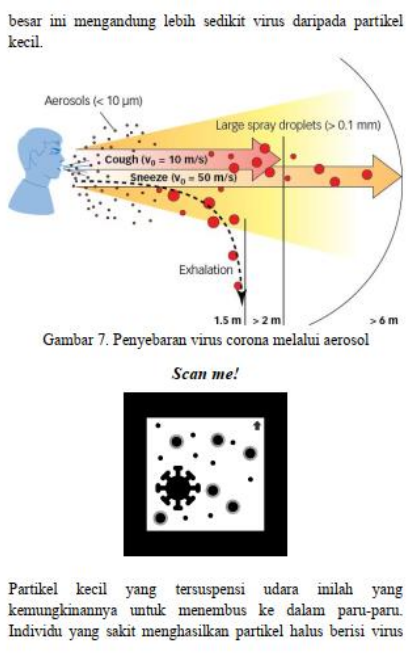

22

(c)

FIGURE 4 (a). The initial appearance of augmented physics animation media in the form of a mobile application; (b) student activity scanning the marker; (c) augmented physics animation handout integrated cross-cutting concept of the COVID-19 pandemic 


\section{CONCLUSION}

Based on the explanation of the results and discussion, it can be concluded that: a) there is no difference in the mastery of student problem-solving skills in the experimental group and the comparison group. Asymp Sig shows a value of 0.187 or $>0.05$, so it can be decided that $\mathrm{H} 1$ is rejected. The implementation of augmented physics animation on students' mastery of problem-solving skills has not yet been seen. This happens because, in augmented physics, animation media only facilitates two aspects of problem-solving, such as understanding the problem and evaluating the solution. b) there is a difference in the level of student COVID-19 disaster preparedness between the experimental group and the comparison group. Asymp Sig shows a value of 0.012 or $<0.05$, so it can be decided that $\mathrm{H} 2$ is accepted. The application of augmented physics animation media can already be seen in facilitating students' preparedness in dealing with the COVID-19 disaster.

\section{ACKNOWLEDGMENT}

Thanks to Universitas Sultan Ageng Tirtayasa, Faculty of Teacher Training and Education through Internal Research and Community Service, Beginner Lecturer Research Scheme for funding this research with contract number T/I/UN43.2/PM.01.01/2020.

\section{REFERENCES}

Afrizon, R \& Dewi, WS 2019, 'Kepraktisan Bahan Ajar Statistika Pendidikan Fisika Bermuatan Model Cooperative Problem Solving', Jurnal Eksakta Pendidikan (JEP), vol. 3, no. 1, pp. 26-33.

Argelagós, E \& Pifarré, M 2012, 'Improving information problem solving skills in secondary education through embedded instruction', Computers in Human Behavior, vol. 28, no 2, pp. 515-526.

Aristiawan, A \& Istiyono, E 2020, 'Developing instrument of essay test to measure the problem-solving skill in physics', Jurnal Pendidikan Fisika Indonesia, vol. 16, no. 2, pp. 72-82.

Astra, IM, Raihanati, R, \& Mujayanah, N 2020, 'Development of Electronic Module Using Creative Problem-Solving Model Equipped with HOTS Problems on The Kinetic Theory of Gases Material', Jurnal Penelitian \& Pengembangan Pendidikan Fisika, vol. 6, no. 2, pp. 181-194.

Docktor, JL 2009, 'Development and validation of a physics problem solving assessment rubrics', Dissertation, University of Minnesota, viewed 20 April, 2020, https://hdl.handle.net/11299/56637.

Ekici, Dİ 2014, 'The Perceptions and Views about Problem avcc Process of Pre-service Science Teachers', Procedia - Social and Behavioral Sciences, vol. 141, pp. 308-312.

Fong, SF, Lily, LPL, \& Por, FP 2012, 'Reducing cognitive overload among students of different anxiety levels using segmented animation', Procedia - Social and Behavioral Sciences. vol.47, pp. $1448-1456$.

Gannika, L \& Sembiring, EE 2020, 'Hubungan tingkat pendidikan dengan perilaku pencegahan coronavirus disease (covid-19) pada masyarakat Sulawesi Utara', NERS Jurnal Keperawatan, vol. 16 , no. 2 , pp. $83-89$.

Guntara, Y, et al. 2021, 'Development of augmented physics animation (APA) with the integration of crosscutting concepts about the COVID-19 as a supplement to the introductory physics course', AIP Conference Proceedings, vol. 2320, no. 1, p. 20025.

Hariawan, H, Kamaluddin, K, \& Wahyono, U 2013, 'Pengaruh model pembelajaran creative problem solving terhadap kemampuan memecahkan masalah fisika pada siswa kelas XI SMA Negeri 4 Palu', JPFT (Jurnal Pendidikan Fisika Tadulako Online), vol. 1, no. 2, pp. 48-54.

Hidayati, DW 2017, 'Diagnosa kesulitan metacognitive awareness terhadap proses pemecahan masalah matematika', JNPM (Jurnal Nasional Pendidikan Matematika), vol. 1, no. 2, pp. 206-217. 
Jeffri, NFS, \& Rambli, DRA 2021, 'A review of augmented reality systems and their effects on mental workload and task performance', Heliyon, p. e06277.

Kwon, K, Kumalasari, CD \& Howland, JL 2011, 'Self-explanation prompts on problem-solving performance in an interactive learning environment', Journal of Interactive Online Learning, vol. 10, no. 2, pp. 96-112.

Madrid, RI, Oostendorp, HV, \& Melguizo, MCP 2009, 'The effects of the number of links and navigation support on cognitive load and learning with hypertext: The mediating role of reading order', Computers in Human Behavior, vol. 25, no. 1, pp. 66-75.

McLennan, J, Marques, MD, \& Every, D 2020, 'Conceptualising and measuring psychological preparedness for disaster: The Psychological Preparedness for Disaster Threat Scale', Nat Hazards vol. 101, pp. 297-307.

Memduhouglu, HB and Kelecs, E 2016, 'Evaluation of the relation between critical-thinking tendency and problem-solving skills of pre-service teachers', Journal of Educational Sciences Research, vol. 6, no. 2, pp. 75-94.

Natalia, RN, Malinti, E, \& Elon, Y 2020, 'Kesiapsiagaan Remaja Dalam Menghadapi Wabah Covid19', NHIHC: Nani Hasanuddin International Health Conference, pp. 107-111.

Nugraha, MG et al. 2017, 'Problem Solving-Based Experiment untuk Meningkatkan Keterampilan Penalaran Ilmiah Mahasiswa Fisika', Jurnal Penelitian $\backslash \&$ Pengembangan Pendidikan Fisika, vol. 3, no. 2, pp. 137-144.

Ploetzner, R et al. 2009, 'Students' difficulties in learning from dynamic visualisations and how they may be overcome', Computers in Human Behavior, vol. 25, no. 1, pp. 56-65.

Safitri, AE \& Toyib, M 2019, 'Kesulitan siswa berdasarkan teori polya ditinjau dari gender dalam menyelesaikan soal Sistem Persamaan Linear Dua Variabel (SPLDV) di SMP Negeri 1 Sambi', Thesis, Universitas Muhammadiyah Surakarta, viewed 20 April, 2020, http://eprints.ums.ac.id/74434/.

Sağlam, Y \& Dost, S 2014, 'Preservice Science and Mathematics Teachers' Beliefs about Mathematical Problem Solving', Procedia - Social and Behavioral Sciences, vol. 116, pp. 303-306.

Sitti, S, Sopeerak, S, \& Sompong, N 2013, 'Development of instructional model based on connectivism learning theory to enhance problem-solving skill in ict for daily life of higher education students', Procedia - Social and Behavioral Sciences, vol. 103, pp. 315-322.

Taasoobshirazi, G \& Farley, J 2013, 'A multivariate model of physics problem solving', Learning and Individual Differences, vol. 24, pp. 53-62.

Umar, N 2013, 'Pengetahuan dan kesiapsiagaan masyarakat menghadapi bencana banjir di bolapapu kecamatan kulawi sigi sulawesi tengah', Jurnal Keperawatan Soedirman, vol. 8, no. 3, pp. 105119.

Valtonen, $\mathrm{T}$ et al. 2021, 'How pre-service teachers perceive their 21st-century skills and dispositions : A longitudinal perspective', Computers in Human Behavior, vol. 116, p. 106643.

Wairata, BEG 2020, 'Hubungan tingkat pengetahuan dan sikap dengan perilaku pencegahan covid-19 pada mahasiswa universitas airlangga Surabaya', Universitas Airlangga.

Warimun, ES 2012, 'Penerapan model pembelajaran problem solving fisika pada pembelajaran topik optika pada mahasiswa pendidikan fisika', Exacta, vol.10, no. 2, pp. 111-114.

Yanti, N. et al. 2020, 'Gambaran pengetahuan masyarakat tentang covid-19 dan perilaku masyarakat di masa pandemi covid-19', J Keperawatan Jiwa, vol. 8, no. 3, pp. 485-490.

Zahro, Z. R. et al, 2017, 'Sekolah siaga bencana: kajian evaluatif kesiapsiagaan sekolah menghadapi bencana', Seminar Nasional Pendidikan Sinergitas Keluarga, Sekolah, dan Masyarakat dalam Penguatan Pendidikan Karakter, pp. 249-258. 